\title{
Evaluation of the use of Leptodactylus ocellatus (Anura: Leptodactylidae) frog tissues as bioindicator of metal contamination in Contas River, Northeastern Brazil
}

\author{
LÍVIA O. CORREIA ${ }^{1}$, SÉRGIO SIQUEIRA JÚNIOR ${ }^{1}$, \\ PAULO L.S. CARNEIRO ${ }^{1}$ and MARCOS A. BEZERRA ${ }^{2}$ \\ ${ }^{1}$ Departamento de Ciências Biológicas, Universidade Estadual do Sudoeste da Bahia, \\ Av. José Moreira Sobrinho, s/n, 45206-191 Jequié, BA, Brasil \\ ${ }^{2}$ Departamento de Química e Exatas, Universidade Estadual do Sudoeste da Bahia, \\ Av. José Moreira Sobrinho, s/n, 45206-191 Jequié, BA Brasil
}

Manuscript received on September 9, 2013; accepted for publication on January 30, 2014

\begin{abstract}
This paper presents a study on the viability of the use of tissues of the Leptodactylus ocellatus species (Anura Leptodactylidae) as a bioindicator of metal pollution. The study is based on the determination and correlation of the concentrations of manganese, chromium, zinc, nickel, copper and iron in sediments and tissues (skin, muscles and viscera) of the frog Leptodactylus ocellatus collected in the middle region of the Contas River in Bahia, Brazil. The highest levels of the metals studied were found in the viscera of this animal. In this tissue, a higher correlation of the concentration of these metals with those found in sediments was also observed. The concentrations of elements found in the skin and muscles of these amphibians have revealed no correlation with the sediment where they were collected. According to the results obtained, the viscera of the L. ocellatus species presents itself as a good bioindicator of contamination by the metals studied.
\end{abstract}

Key words: Leptodactylus ocellatus, bioindicators, sediments, metals, Contas River.

\section{INTRODUCTION}

Aquatic environments, soils and atmosphere are constantly exchanging matter and energy. Thus, contaminants can pass from one ecosystem compartment to another very quickly (Domingos 1998). As part of these environments, living beings are also subject to the effects of these pollutants, which can be mutagenic, teratogenic or toxic, damaging the survival of populations (Bulbovas et al. 2008) and accumulating in food chains, when they are passed from one trophic level to another (Odum and Barret 2008).

Correspondence to: Marcos de Almeida Bezerra

E-mail:mbezerra@uesb.edu.br
Analysis of water and sediments is important for environmental monitoring, but does not provide adequate information on the amount of metal incorporated into the biomass (Baraj et al. 2009). This evaluation requires the use of vegetable or animal organisms as bioindicators. An organism must present certain characteristics in order to be classified as a good bioindicator: it must be taxonomically well-defined and easily recognizable by non-specialists, provide wide geographical distribution (being abundant or easy to collect); have low genetic and ecological variability, low mobility and a long life cycle, present well known ecological characteristics and be viable for laboratory studies. (Johnson et al.1993). 
There are many studies evaluating the use of bioindicators, and most of them use macroinvertebrates, such as mollusks, crustaceans and dipteras, among others. The studies of Beltrame et al. (2011), in which the crustacean Neohelice granulata was evaluated as bioindicator, serves as an example. The presence of metals in these organisms in different seasons was analyzed, confirming the existence of a positive correlation in the variation of contaminant concentrations in accordance with the season studied.

Amphibians are used as bioindicators of metal contamination, as they play an important role in aquatic ecosystems, having their life cycles in the water as tadpoles and on land and water after undergoing metamorphosis (Greenhouse 1976, Schuytema et al. 1991, Bueno-Guimarães et al. 2001).

The sensitivity of amphibians to various chemical contaminants has been evaluated in several studies. Schuytema and Nebeker (1999) analyzed the growth and death of amphibian species Rana aurora exposed to ammonium nitrate and sodium nitrate and tadpoles of the species Xenopus laevis and Pseudacris regilla exposed to urea. Marques et al. (2011) studied the contamination of amphibian species Pelophylax perezi in an uranium mine and a non-anthropic reference site and found that some elements may be up to 1000 times more concentrated in mining areas. Nations et al. (2011) evaluated the acute effects of $\mathrm{ZnO}, \mathrm{TiO}_{2}, \mathrm{Fe}_{2} \mathrm{O}_{3}$, and $\mathrm{CuO}$ in Xenopus laevis and demonstrated that at trace concentrations these compounds were not harmful to the organisms studied.

With a wide distribution in Brazil and close relationship with aquatic and terrestrial environments, the Leptodactylus ocellatus can be a good tool for environmental biomonitoring. This paper evaluates the efficiency of the use of $L$. ocellatus as an organism bioindicator of contamination by metals. In this study, we determined the concentrations of $\mathrm{Mn}, \mathrm{Cr}, \mathrm{Zn}, \mathrm{Ni}$, $\mathrm{Cu}$ and $\mathrm{Fe}$ in different tissues of this species, in order to assess what tissue proved to be more effective as a bioindicator of contamination. To corroborate the results found in amphibians, these elements were also determined in sediment samples collected on the same place where frogs were found.

\section{MATERIALS AND METHODS}

LOCATION OF THE STUDY

The Contas River is the most important river of its basin and it is included among the five most important waterways in the state of Bahia. It rises in a geographic region characterized by plateaus called "Chapada Diamantina" and flows into the town of Itacare in Bahia, covering about $500 \mathrm{~km}$ (Figure 1). The Contas watersheds is located in the central south of the state, with the geographical coordinates $12^{\circ} 55^{\prime}$ and $15^{\circ} 10^{\prime}$ south latitude and $39^{\circ} 00^{\prime}$ and $42^{\circ} 35^{\prime}$ west longitude. It is bounded on the north by the Paraguaçu River and south rivers from "Recôncavo" (a region comprised of lands that surround the "Todos os Santos" Bay), on the south by the state of Minas Gerais, with the Pardo river basin and east basins, on the east by the Atlantic Ocean and west by the São Francisco River basin (SRH 2007).

The area of the Contas River watershed presents eight phytoecological regions: savanna, forest vines, rocky fields, forest, dunes and mangrove. Thereby being presented in three physiographic regions with very different characteristics, such as the High, Middle and Lower regions of the Contas River (PDRH 1993).

The economic activities near the basin of the Contas River are characterized by a strong predominance of agriculture which accounts for $64 \%$ of the economically active population in the region. Irrigated agriculture is present in 37 of the 63 counties of the basin, with great potential for development due to its prospective soil, water availability, and primarily due to the existing traditions in the region (SRH 2007).

However, mining, sewage disposal and other effluents, as well as other industrial also developed along the river, especially near the city of Jequié (Middle region of the Contas), and these contribute 


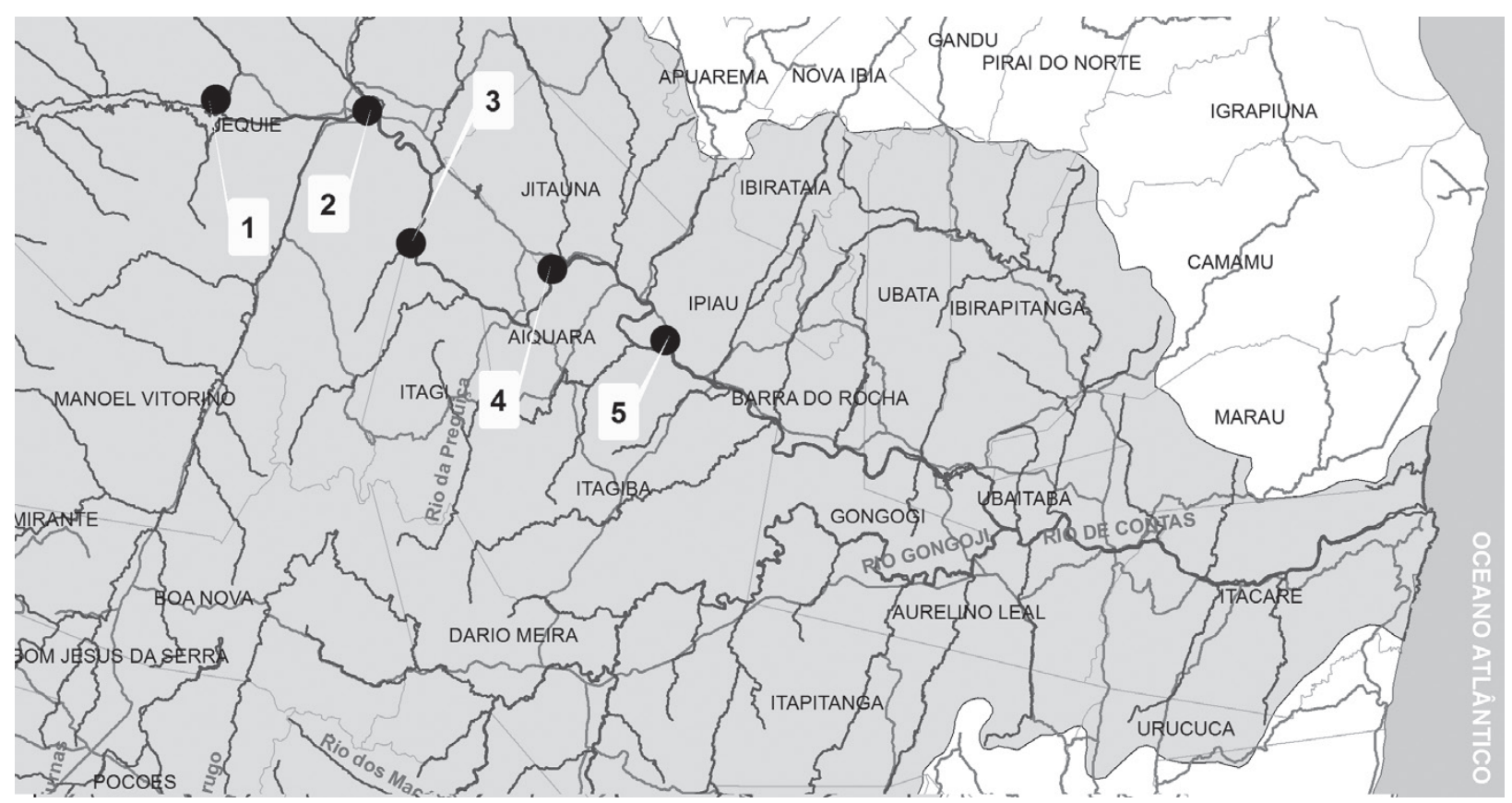

Figure 1 - Sampling points of specimens of Leptodactylus ocellatus.

to the contamination of the river (Sá and Sá 2004). The Contas River is used for various purposes, and its current state of degradation highlights the need for biomonitoring focused on its recovery and/or conservation, thus ensuring the quality and quantity of the resources it can offer.

\section{SAMPLES}

Twenty specimens of Leptodactylus ocellatus and five sediment samples from five points were collected in the Middle Region of the Contas River
(Table I) between November 2010 and March 2011. Analysis was performed on different tissues: skin, muscle and viscera. The procedures adopted for the experimental treatments with the animals have been evaluated and approved by the Ethics Committee for animal use (Protocol 75/2014) of the Universidade Estadual do Sudoeste da Bahia (UESB).

Water and sediment samples were collected at $2.0 \mathrm{~m}$ from the shore, sent to the laboratory and stored at $4^{\circ} \mathrm{C}$ until analysis. Sediment samples were collected using a cylindrical sampler made of PVC

TABLE I

Georeferenced points for sediment and $L$. ocellatus sample collection.

\begin{tabular}{|c|c|c|c|c|c|}
\hline Point of Collection & Location Type & Location name & Use of nearby areas & Coordinates & Altitude (m) \\
\hline P1 & Rural & Dam, Jequié & $\begin{array}{l}\text { Public water supply } \\
\text { and recreation }\end{array}$ & $\begin{array}{l}13^{\circ} 51^{\prime} 40^{\prime \prime} \mathrm{S} \\
40^{\circ} 14^{\prime} 599^{\prime \prime} \mathrm{O}\end{array}$ & 238 \\
\hline $\mathrm{P} 2$ & Urban & $\begin{array}{l}\text { Behind the Aliança } \\
\text { tannery, Jequié }\end{array}$ & $\begin{array}{l}\text { Residence and } \\
\text { raw sewage }\end{array}$ & $\begin{array}{l}13^{\circ} 52^{\prime} 24^{\prime \prime} \mathrm{S} \\
40^{\circ} 04^{\prime} 37^{\prime} \mathrm{O}\end{array}$ & 189 \\
\hline P3 & Rural & $\begin{array}{l}\text { Frisuba village, } \\
\text { Jequié }\end{array}$ & Livestock raising & $\begin{array}{l}13^{\circ} 55^{\prime} 14^{\prime \prime} \mathrm{S} \\
40^{\circ} 01^{\prime} 44^{\prime \prime} \mathrm{O}\end{array}$ & 183 \\
\hline P4 & Rural & $\begin{array}{c}\text { Jitaúna country } \\
\text { area }\end{array}$ & $\begin{array}{c}\text { Agriculture, Livestock } \\
\text { raising }\end{array}$ & $\begin{array}{l}14^{\circ} 03^{\prime} 65^{\prime \prime} \mathrm{S} \\
39^{\circ} 54^{\prime} 87^{\prime \prime} \mathrm{O}\end{array}$ & 165 \\
\hline P5 & Urban & Center of Ipiaú city & Residence & $\begin{array}{l}14^{\circ} 07^{\prime} 63^{\prime \prime} \mathrm{S} \\
39^{\circ} 45^{\prime} 48^{\prime \prime} \mathrm{O}\end{array}$ & 141 \\
\hline
\end{tabular}


at a distance of $2 \mathrm{~m}$ from the riverbank. Sticks and stones collected with the sediments were manually removed. The samples were packed in plastic bags, sent to the laboratory and dried at $60^{\circ} \mathrm{C}$ for $24 \mathrm{~h}$.

\section{INSTRUMENTS AND MATERIALS}

In order to determine the analytes, a flame atomic absorption spectrometer (FAAS) Perkin Elmer (Norwalk, CT, USA) model AAnalyst 200 equipped with deuterium lamp background correction was used. The hollow cathode lamps were used for each element in accordance with the manufacturer's recommendations. The wavelengths chosen for reading the absorbance corresponding to each element were $324.8(\mathrm{Cu}), 248.3(\mathrm{Fe}), 279.5(\mathrm{Mn})$, $232.0(\mathrm{Ni}), 213.9(\mathrm{Zn})$ and $357.9(\mathrm{Cr}) \mathrm{nm}$. The width of the slit of the monochromator used to measure copper, zinc and chromium was $0.7 \mathrm{~nm}$, for the determination of iron, manganese and nickel, the corresponding value was $0.2 \mathrm{~nm}$. The height of the burner $(13.5 \mathrm{~mm})$ was also used with conventional values. The gas mixture used to keep the flame consisted of acetylene (flow rate $2.0 \mathrm{~mL} \mathrm{~min}^{-1}$ ) and air (flow rate $13.5 \mathrm{~L} \mathrm{~min}^{-1}$ ). The aspiration of the

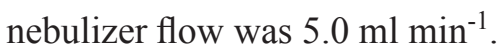

The digestion of the samples of animal tissue or extraction of analytes from sediments was performed using a microwave oven joint (Britain, 19L, 700W) and pumps Teflon with safety device for pressure relief (Parr Model 4781, capacity 23 $\mathrm{ml}$, maximum temperature of $250^{\circ} \mathrm{C}$ and pressure of 1200 psi) (EPA 2007). A drying oven (DeLeo, model A2-EDS) was used for drying the material collected. Porcelain mortar and pestle and Tamise fine mesh $(65 \mu \mathrm{m})$ were used for grinding and sieving the samples.

\section{REAGENTS}

All solutions were prepared with ultra pure water (resistivity of $18.2 \mathrm{M} \Omega \mathrm{cm}$ ) obtained from a purification system (ELGA, model Classic UF MK2). The glassware was decontaminated with nitric acid (Fmaia) 5\% (v/v). Nitric acid PA (65\%) of Fmaia, water and hydrogen peroxide PA (Fulka) were used for the digestion of the samples. Standard solutions originating from Fluka Analytical, concentrations of $1000 \mathrm{mg} \mathrm{L}^{-1}$ of each element (Fe, $\mathrm{Ni}, \mathrm{Mn}, \mathrm{Zn}, \mathrm{Cu}$ and $\mathrm{Cr}$ ) were used for calibration. Sulfuric acid (Fmaia) was used to break down the fat of the biological material during the drying process.

SAMPLES PREPARATION

\section{Sediments}

The sediments were dried at $60^{\circ} \mathrm{C}$ for $24 \mathrm{~h}$. Then crushed in mortar and pestle and sieved. The bioavailable metals were extracted following the protocol EPA 3051 with modifications. To a quantity of $0.1 \mathrm{~g}$ of sediment, $2.0 \mathrm{~mL}$ of nitric acid P.A. were added, in a Parr vessel for acid digestion. The system was subjected to microwave irradiation for 120 seconds at a power of about $350 \mathrm{~W}$. After cooling at room temperature, the mixture was filtered and transferred to $10 \mathrm{ml}$ flasks and the volume was completed with ultra-pure water.

\section{Leptodactylus ocellatus tissues}

Amphibians were taken to the laboratory where they were washed with deionized water. Euthanasia was performed with hypothermia and weighing was done in a semi-analytical scale. After euthanasia, tissues were carefully separated to avoid contamination, weighed and kept in an incubator at $60^{\circ} \mathrm{C}$ for six days. After drying, the material was weighed again in order to calculate the moisture. The amphibians collected in the same location that did not reach $40 \mathrm{~g}$ of wet weight were grouped in order to supply sufficient mass for sampling.

Samples from different tissues from the fractionation of amphibians samples were prepared using $0.1 \mathrm{~g}$ of the material mixed with $2.0 \mathrm{ml}$ of concentrated $\mathrm{HNO}_{3}, \mathrm{H}_{2} \mathrm{O}$ and $1 \mathrm{ml}$ of $0.4 \mathrm{ml}$ of $\mathrm{H}_{2} \mathrm{O}_{2}$. Then the mixture was taken to a microwave oven where it was irradiated for 90 seconds, at a 
mean power of $350 \mathrm{~W}$. After cooling, the digest was transferred to a $10.00 \mathrm{~mL}$ volumetric flask, whose volume was then completed with ultra-pure water.

\section{DATA ANALYSIS}

Statistica 7.0 software was used for principal component analysis (PCA) and hierarchical cluster analysis (HCA) application. In order to calculate the correlations between the variables, the SAS 9.0 software (Statistical Analysis System Institute Inc. user's guide Version 9.1 ed. Cary) was used. Excel was used for obtaining analytical curves. Quantitative variables were determined from the mean Euclidean distance and UPGMA. In all statistical analyses we used the confidence level of $95 \%(\alpha=0.05)$.

\section{RESULTS AND DISCUSSION}

Average concentrations and standard deviation of $\mathrm{Mn}, \mathrm{Cr}, \mathrm{Zn}, \mathrm{Ni}, \mathrm{Cu}$ and $\mathrm{Fe}$ for sediment samples are presented in Table II and those of the different tissues of Leptodactylus ocellatus collected along the banks of the Contas River, Bahia, are shown in Table III. The metal concentrations are given in micrograms per gram $\left(\mathrm{mg} \mathrm{g}^{-1}\right)$ in a dry weight basis. The quantification limits for the FAAS was 1.6, 11.0, 0.3, 1.9, 0.4, $1.8 \mathrm{mg} \mathrm{g}^{-1}$ for $\mathrm{Mn}, \mathrm{Cr}, \mathrm{Zn}$, $\mathrm{Ni}, \mathrm{Cu}$ and $\mathrm{Fe}$, respectively. Certified reference material was used to validate the method applied for the determination of the metals studied, i.e., to verify whether reliable results were generated. The standard reference material of mussel tissues (CER, CE278, from the Institute for Materials and Reference Measurements, IRMM, Geel, Belgium) was likewise digested from other samples. The values of certified reference samples are presented in Table IV.

In this study, Leptodactylus ocellatus was fractionated into three parts: skin, muscle and

TABLE II

Levels of trace elements found in sediment samples in $\mathrm{mg} \mathrm{g}^{-1}$.

\begin{tabular}{cccccccl}
\hline Matrix & Sample & Mn & Cr & Zn & Ni & Cu & \multicolumn{1}{c}{ Fe } \\
\hline & 1 & $50.0 \pm 2.36$ & $37.9 \pm 3.62$ & $30.7 \pm 2.18$ & $19.5 \pm 2.18$ & $8.10 \pm 1.40$ & $2032 \pm 30.30$ \\
Sediment & 2 & $241 \pm 3.87$ & $96.9 \pm 1.81$ & $79.6 \pm 7.93$ & $36.9 \pm 4.59$ & $19.0 \pm 1.46$ & $2131 \pm 18.23$ \\
& 3 & $32.7 \pm 3.57$ & $40.5 \pm 7.25$ & $6.80 \pm 2.53$ & $14.2 \pm 2.18$ & $1.78 \pm 0.410$ & $1278 \pm 124.48$ \\
& 4 & $409 \pm 139$ & $30.3 \pm 7.25$ & $18.4 \pm 7.10$ & $14.8 \pm 1.65$ & $2.93 \pm 0.201$ & $1964 \pm 15.15$ \\
& 5 & $69.4 \pm 8.59$ & $40.5 \pm 15.8$ & $18.4 \pm 2.98$ & $16.6 \pm 0.82$ & $5.52 \pm 0.701$ & $1911 \pm 38.40$ \\
\hline
\end{tabular}

TABLE III

Content of trace elements found in tissue samples from L. ocellatus ( $\mathrm{mg} \mathrm{g}^{-1}$ ) and standard deviation.

\begin{tabular}{cccccccc}
\hline Matrix & Sample & Mn & Cr & Zn & Ni & Cu & Fe \\
\hline \multirow{5}{*}{ Visceras } & 1 & $5.71 \pm 2.40$ & $<$ LQ & $94.2 \pm 21.59$ & $9.61 \pm 0.89$ & $8.58 \pm 1.87$ & $449 \pm 14.2$ \\
& 2 & $10.5 \pm 6.57$ & $24.7 \pm 6.11$ & $113.2 \pm 21.18$ & $14.9 \pm 2.94$ & $13.6 \pm 2.34$ & $500 \pm 53.2$ \\
& 3 & $4.86 \pm 0.901$ & $<\mathrm{LQ}$ & $93.2 \pm 22.60$ & $18.0 \pm 1.55$ & $3.51 \pm 0.981$ & $358 \pm 32.2$ \\
& 4 & $14.2 \pm 0.873$ & $13.2 \pm 3.47$ & $132 \pm 4.59$ & $13.7 \pm 0.88$ & $8.77 \pm 0.823$ & $382 \pm 49.2$ \\
& 5 & $9.68 \pm 1.24$ & $<\mathrm{LQ}$ & $72.9 \pm 2.85$ & $12.7 \pm 1.47$ & $9.01 \pm 0.26$ & $324 \pm 14.4$ \\
\hline \multirow{5}{*}{ Skin } & 1 & $5.20 \pm 0.931$ & $<\mathrm{LQ}$ & $94.3 \pm 5.31$ & $16.3 \pm 0.894$ & $0.973 \pm 0.600$ & $158 \pm 16.0$ \\
& 2 & $6.30 \pm 1.18$ & $15.7 \pm 2.00$ & $113 \pm 48.71$ & $18.9 \pm 0.671$ & $0.761 \pm 1.04$ & $167 \pm 44.7$ \\
& 3 & $8.41 \pm 1.03$ & $<\mathrm{LQ}$ & $96.5 \pm 6.45$ & $17.7 \pm 4.10$ & $<\mathrm{LQ}$ & $159 \pm 59.2$ \\
& 4 & $9.64 \pm 1.13$ & $<\mathrm{LQ}$ & $109 \pm 32.21$ & $17.6 \pm 2.02$ & $<\mathrm{LQ}$ & $161 \pm 18.4$ \\
& 5 & $8.83 \pm 1.25$ & $13.2 \pm 6.93$ & $154 \pm 29.86$ & $21.1 \pm 2.05$ & $<\mathrm{LQ}$ & $142 \pm 14.8$ \\
\hline \multirow{5}{*}{ Muscle } & 1 & $<\mathrm{LQ}$ & $11.6 \pm 6.11$ & $41.9 \pm 12.15$ & $17.2 \pm 11.0$ & $<\mathrm{LQ}$ & $62.2 \pm 12.4$ \\
& 2 & $<\mathrm{LQ}$ & $14.9 \pm 2.31$ & $50.1 \pm 7.61$ & $14.6 \pm 12.3$ & $<\mathrm{LQ}$ & $58.3 \pm 13.7$ \\
& 3 & $<\mathrm{LQ}$ & $16.5 \pm 8.33$ & $43.2 \pm 16.55$ & $18.7 \pm 7.25$ & $<\mathrm{LQ}$ & $69.9 \pm 16.6$ \\
& 4 & $<\mathrm{LQ}$ & $12.0 \pm 6.37$ & $40.5 \pm 19.02$ & $16.2 \pm 7.99$ & $0.600 \pm 1.02$ & $50.3 \pm 19.2$ \\
& 5 & $2.67 \pm 3.56$ & $14.9 \pm 4.62$ & $39.1 \pm 22.58$ & $17.2 \pm 4.35$ & $0.550 \pm 0.540$ & $78.5 \pm 11.4$ \\
\hline
\end{tabular}


viscera, to determine which of these fractions is most suitable for studies of environmental contamination by metals. The purpose of dividing this study into

TABLE IV

Levels of trace elements in certified reference material $\left(\mathrm{mg} \mathrm{g}^{-1}\right)$.

\begin{tabular}{ccc}
\hline Metals & \multicolumn{2}{c}{ Mussel tissue (CE 278) } \\
\hline & Found & Certified value \\
$\mathbf{M n}$ & $6.81 \pm 0.81$ & $7.69 \pm 0.231$ \\
$\mathbf{C r}$ & $0.9 \pm 0.1$ & $0.78 \pm 0.062$ \\
$\mathbf{Z n}$ & $79.2 \pm 3.46$ & - \\
$\mathbf{N i}$ & $9.85 \pm 1.26$ & - \\
$\mathbf{C u}$ & $8.96 \pm 0.65$ & $9.45 \pm 0.131$ \\
$\mathbf{F e}$ & $86.0 \pm 1.64$ & $83.1 \pm 1.70$ \\
\hline
\end{tabular}

fractions was to avoid misinterpretations when analyzing the whole system, as tissues have the capacity of absorbing each element differently.

Using the concentrations obtained from the analysis of the frog tissue samples and sediments as chemical descriptors, PCA and HCA were applied to data exploration and pattern recognition. First, these statistical techniques were applied to the data of all tissue samples. The analysis results of this pooled data are presented as scores, loadings and dendrogram graphicals (Figure 2). The $\mathrm{Cr}$ variable was excluded from the analysis because this
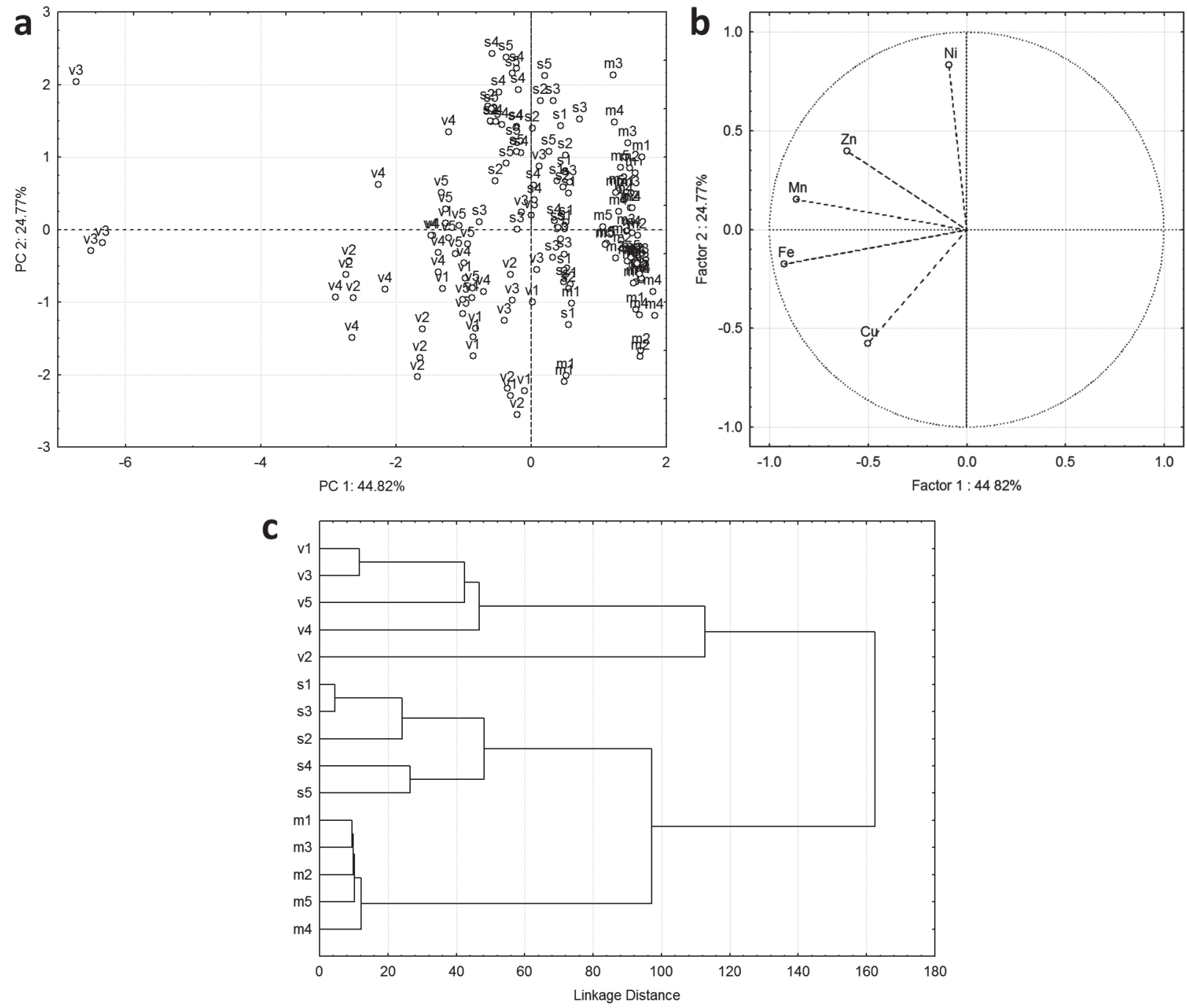

Figure 2 - Multivariate analysis of data obtained from metal determination in tissues of L. ocellatus collected in Contas River: (a) score, (b) loading and (c) dendogram plots. 
variable presents little contribution to modeling data. The percentage of variance explained by the first two PCs (69.59) were considered sufficient in describing the behavior of the data. Analyzing the graph of scores (Figure 2a), it was noted that the samples tended to form a group according to the types of analyzed tissues. The more dispersed group consisted of samples of viscera, and three of these samples (on the left of the graph) stand out from the rest. The loadings plot (Figure 2b) reveals that it is formed by samples of viscera seems to stand out from the other groups due to their contents of $\mathrm{Fe}$ and $\mathrm{Cu}$. The $\mathrm{Mn}$ had great influence on the segregation of three samples of viscera from the rest of the group. $\mathrm{Ni}$ and $\mathrm{Zn}$ variables contributed to the grouping the skin samples and the $\mathrm{Ni}$ and $\mathrm{Cu}$ were the main variables responsible for grouping the samples of muscles. The dendrogram in Figure $2 \mathrm{c}$ corroborates the interpretations made in the PCA. This joint analysis reveals that the three tissues have different behaviors in relation to the accumulation of the metals studied and that the factor "tissue type" overlaps the factor "collection site" in the definition of the formed groups.
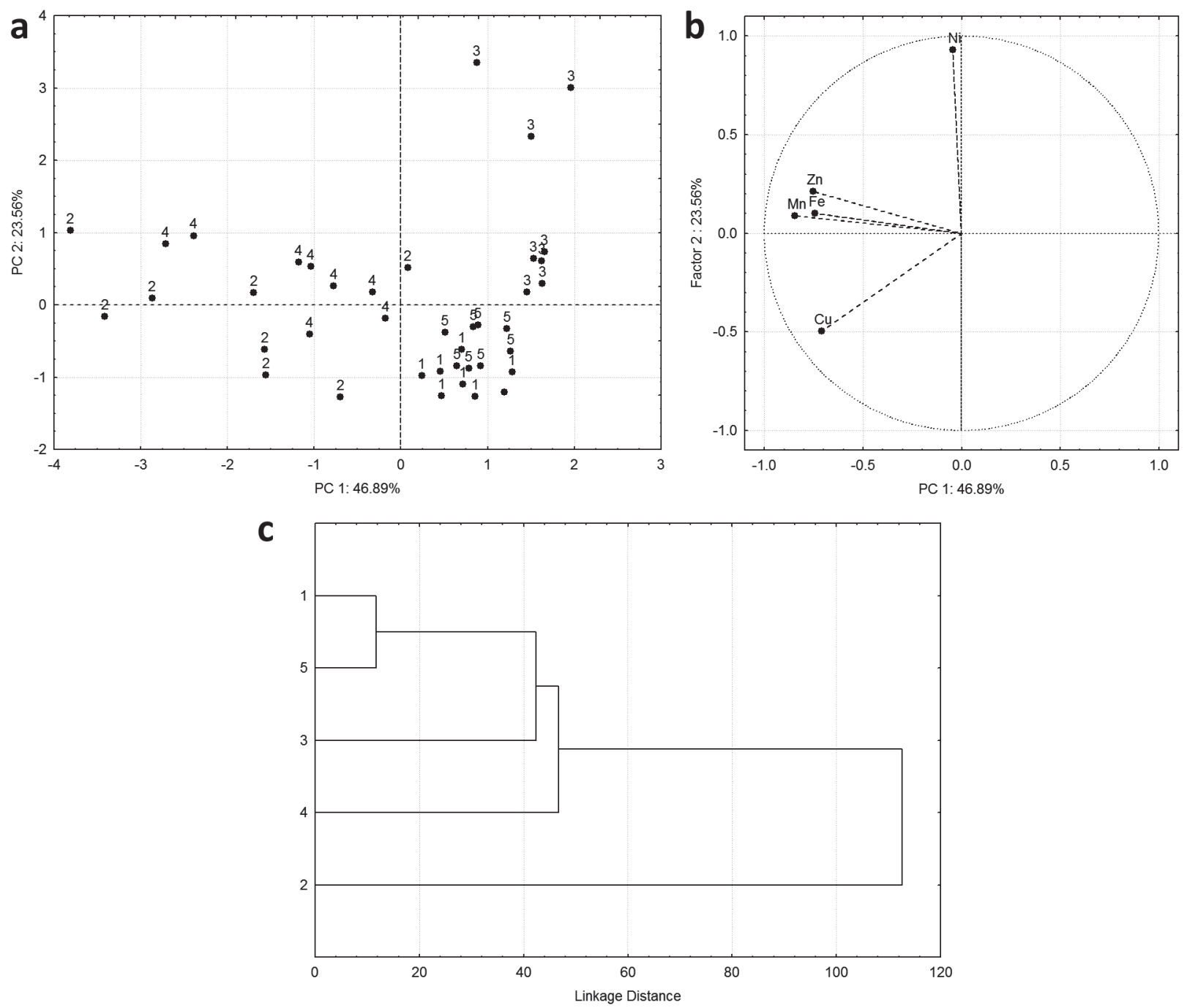

Figure 3 - Multivariate analysis of data obtained from metal determination in viscera of L. ocellatus collected in Contas River: (a) score, (b) loading and (c) dendogram plots. 
The tissues were also analyzed separately. Figure 3 presents the principal component analysis of viscera samples. In this analysis the variable Cr was removed for not contributing significantly in the data modeling. The percentage of variance explained by the first two PCs was 70.45 and also considered satisfactory. The scores plot (Figure 3a) reveals that samples of viscera have a tendency to group according to the place of specimen collection. The samples from sampling sites 1 and 5 were the most similar and less dispersed. These findings can be reinforced by the dendrogram presented in
Figure 3c. It still shows that group 2 is less similar among all. Analyzing the loadings plot (Figure $3 b)$ we note that $\mathrm{Ni}$ is mainly responsible for the behavior of Group 3 and $\mathrm{Cu}$ and $\mathrm{Mn}$ are the main variables that highlight group 2 . The $\mathrm{Cu}$ is also the main variable allowing for the separation of groups 1 and 5 while the $\mathrm{Zn}$ and $\mathrm{Fe}$ are the main variables that allow the distinction of group 4.

Figure 4 depicts graphs from multivariate analysis of the skin samples. In this analysis the variable $\mathrm{Cr}$ was removed for not contributing significantly in modeling data. The first two PCs together explain
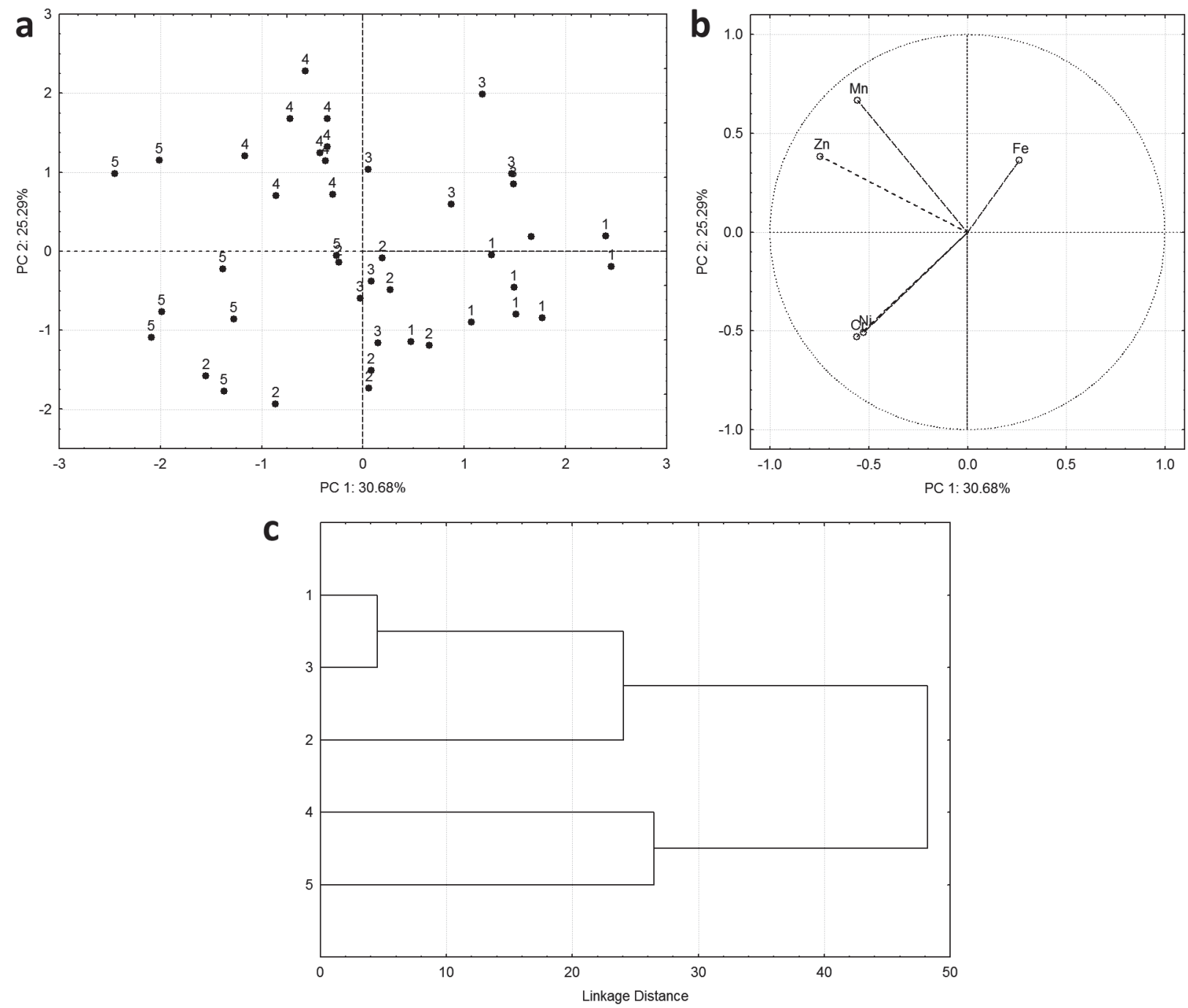

Figure 4 - Multivariate analysis of data obtained from metal determination in skin of L. ocellatus collected in Contas River: (a) score, (b) loading and (c) dendogram plots. 
$55,97 \%$ of the total variance. Even though some samples are mixed with samples belonging to other groups, there is a tendency to forming groups according to the location where the specimens were collected. Samples collected in Section 5 are the most dispersed and $\mathrm{Ni}$ and $\mathrm{Cu}$ are the variables that contributed the most to this group. Iron is the main discriminant for group 3 and $\mathrm{Mn}$ and $\mathrm{Zn}$ contributed to the formation of group 4 . The dendrogram of Figure $4 \mathrm{c}$ shows that, using a linkage distance of 30 , there is the formation of a group composed by samples collected at points 1,2 and 3 and another group formed by samples of points 4 and 5 .

When analyzing samples of muscle tissue separately, it is noted by the scores plot (Figure 5) that, except for group 5, groups formation for other samples are not clear. In this analysis, the PC1 and PC2 explain $61,48 \%$ of the data variation and variable $\mathrm{Ni}$ was removed due it not contributing significantly in the modeling data. The grouping of the samples collected in the point 5 derives from the contribution of $\mathrm{Mn}$ and $\mathrm{Fe}$ variables. HCA corroborates this conclusion. Using a linkage distance of 10.5 , it is noted that there is a formation
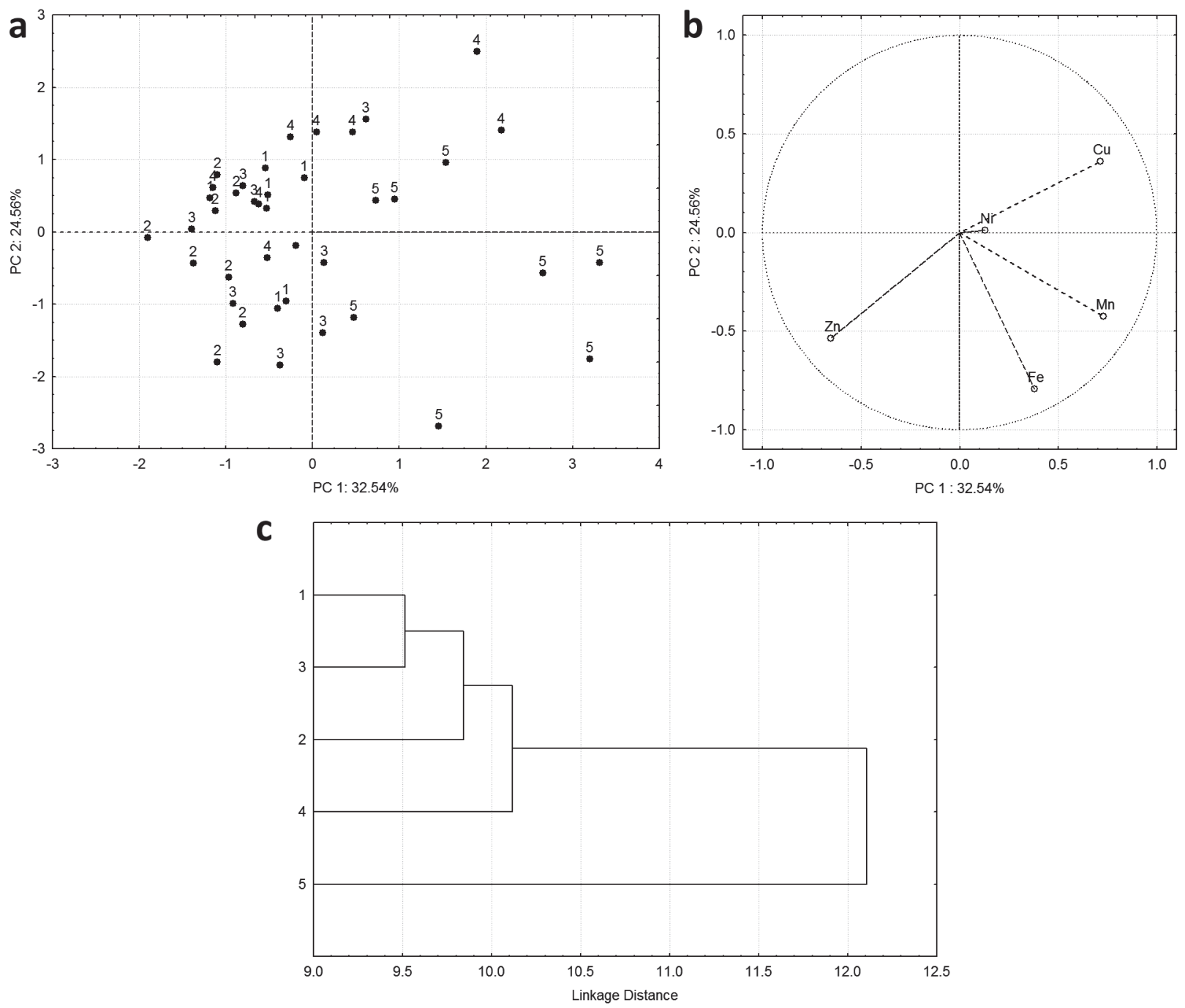

Figure 5 - Multivariate analysis of data obtained from metal determination in muscle of L. ocellatus collected in Contas River: (a) score, (b) loading and (c) dendogram plots. 

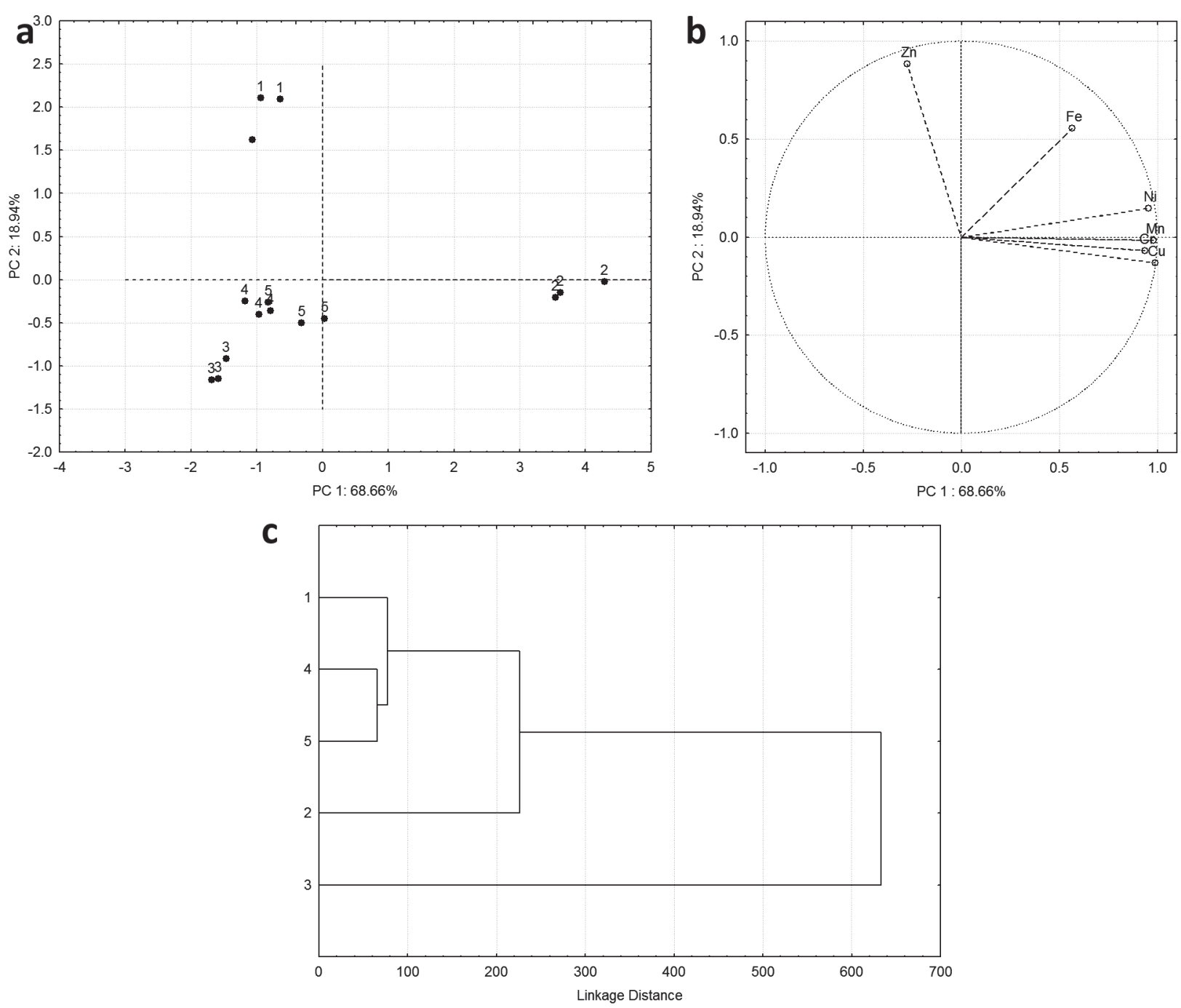

Figure 6 - Multivariate analysis of data obtained from metal determination in sediments of L. ocellatus collected in Contas River: (a) score, (b) loading and (c) dendogram plots.

of a group composed of the samples collected in the point 5 and the other composed by samples collected at points 1, 2, 3 and 4 .

For the data obtained by analysis of sediments, scores plot (Figure 6a) revealed the formation of three groups. One of these groups is formed by sediment samples collected in the points 3, 4 and 5 . The other two groups are formed by the samples of point 1 and point 2, respectively. The loadings plot (Figure 6b) reveals that all variables are important in the mathematical modeling which enables groupings and the creation of the dendrogram with the findings obtained in the PCA.
Thus, after performing the multivariate data analysis, it can be concluded that the levels of metals can be analyzed in regards to the type of tissue obtained from the frog Leptodactylus ocellatus. There is also a trend of clustering of samples of viscera and skin according to the location at which the specimen was collected. For samples of muscle, the formation of groups in relation to the collection site was not well defined.

Table V shows the correlation between the levels of metals found in sediment with the levels present in some tissues of the specimens analyzed. The highest positive correlation was seen between the content of 
TABLE V

Correlation between metal contents in sediments and in tissues of Leptodactylus ocellatus.

\begin{tabular}{cccccccc}
\hline & & \multicolumn{7}{c}{ SEDIMENT } \\
\hline MATRIX & Element & Mn & $\mathbf{C r}$ & $\mathbf{Z n}$ & $\mathbf{N i}$ & $\mathbf{C u}$ & $\mathbf{F e}$ \\
\hline \multirow{6}{*}{ Skin } & $\mathrm{Mn}$ & $0.17(0.78)$ & - & - & - & - & - \\
& $\mathrm{Cr}$ & - & $-0.27(0.65)$ & - & - & - & - \\
& $\mathrm{Zn}$ & - & - & $0.06(0.91)$ & - & - & - \\
& $\mathrm{Ni}$ & - & - & - & $-0.03(0.96)$ & - & - \\
& $\mathrm{Cu}$ & - & - & - & - & $-1.00(0.0)$ & - \\
& $\mathrm{Fe}$ & - & - & - & - & - & $0.14(0.82)$ \\
\hline \multirow{6}{*}{ Muscle } & $\mathrm{Mn}$ & $1.00(0.0)$ & - & - & - & - & - \\
& $\mathrm{Cr}$ & - & $0.34(0.57)$ & - & - & - & - \\
& $\mathrm{Zn}$ & - & - & $0.86(0.05)$ & - & - & - \\
& $\mathrm{Ni}$ & - & - & - & $-0.81(0.09)$ & - & - \\
& $\mathrm{Cu}$ & - & - & - & - & $0.87(0.34)$ & - \\
& $\mathrm{Fe}$ & - & - & - & - & - & $0.40(0.49)$ \\
\hline \multirow{6}{*}{ Viscera } & $\mathrm{Mn}$ & $0.91(0.03)$ & - & - & - & - & - \\
& $\mathrm{Cr}$ & - & $0.88(0.05)$ & - & - & - & - \\
& $\mathrm{Zn}$ & - & - & $0.29(0.63)$ & - & - & - \\
& $\mathrm{Ni}$ & - & - & - & $0.005(0.99)$ & - & - \\
& $\mathrm{Cu}$ & - & - & - & - & $0.86(0.05)$ & - \\
& $\mathrm{Fe}$ & - & - & - & - & - & $0.56(0.32)$ \\
\hline
\end{tabular}

* The values in parentheses represent the value of $p$.

Mn in sediments with Mn content in the viscera (0.91), followed by the correlation of $\mathrm{Cr}(0.88)$ and $\mathrm{Cu}(0.87)$ between the same segments. Amidst the correlations between the metals present in the sediment and the muscles, the only significant positive correlation found, was between the levels of zinc (0.86) and Mn (1.00). On the skin, there was significant negative correlation with the sediment for $\mathrm{Cu}$. The remaining values were disregarded, as they were not significant.

From the results and correlation analysis, it was observed that the metals found in the skin did not show the same behavior as those found in sediment. Of all tissues analyzed, the group formed for skin showed the greatest differences. Tests on the correlation between the $\mathrm{Zn}, \mathrm{Mn}$ and $\mathrm{Fe}$ of the skin and the sediment, did not prove significant. Through the determination of metal in the skin, it was observed that this matrix possesses high levels of zinc. However, the quantity of zinc that reaches other body tissues is relatively low (Whittaker 1998). High concentrations of iron were also found, which can be explained by the high level of iron in the water and sediment of the Contas River, as the region is rich in iron ore. Mn concentration in the skin, viscera and muscle were relatively low compared to amounts found in the sediments. Although the region contains a large amount of $\mathrm{Mn}$, as it is being released in the waste generated in household chores, this is not being accumulated in the organism. The concentration of $\mathrm{Cu}$ in all samples analyzed was very low in comparison to other studies. It was not possible to be determined in some samples of skin, as it was below the quantification limit of the analytical technique used. The low copper content found in the samples can be explained by the limited availability of copper present in the environment. Furthermore, bioavailability depends not only on metal species, but also on other substances in the environment (WHO 1998a). The presence of $\mathrm{Cr}$ in the samples can be explained by the fact that the studied region is close to a tannery, no longer in use, in which chrome was used for tanning leather only a 
few years ago. In addition, the fact that the region is rich in concentrated nickel, explains the presence of this metal in the samples.

In the analysis of the muscles it could be seen some differences in relation to the results found in the skin. The manganese concentrations in the muscles were lower than in the skin and viscera. Studies that have determined Mn in the muscles of cattle (Jarvisalo et al. 1992) indicated levels similar to those found in this study. According to WHO (1998b), the food chain does not influence the bioaccumulation and biomagnification of manganese from various sources of contamination by the element. Statistical analysis showed that the muscles of L.ocellatus were not good indicators of pollution since the results remain constant regardless of the variations found in the sediment samples analyzed. The muscles of L.ocellatus are a source of food for the local population. Therefore, noting that the concentrations of metals in these tissues are low, this observation allows discard them as a mean of metal contamination.

Among tissues, the viscera showed the strongest correlation with the sediment. A positive correlation was found between all the metals, however, only $\mathrm{Mn}, \mathrm{Cr}$ and $\mathrm{Cu}$ were significant $(\mathrm{p}<0.05)$. Several studies indicate the viscera as a good indicator of contamination. Liang et al. (1999) investigated the accumulation of metals in the viscera of fish and found that the concentration was inversely proportional to the size of the fish. Traces of sediments found in the viscera of analyzed amphibians suggest probable geophagic and/or fossorial habits, explaining the close relationship between the levels of metals found in both types of samples.

The results obtained in this study showed that there are different concentrations of metals in sediments of urban and rural areas. This suggests that urban areas are the most impacted and that the bioavailability of these pollutants is significantly different. In this sense, human activities shown in Table I may act as potential sources of metals in these environments.
An efficient biological indicator, should reflect levels of environmental contamination, and the relationship between the elements present in the organism and the environment must be constant (Depledge and Fossi 1994). Considering the results of this study and the above requirements, the viscera of L.ocellatus proved to be a piece of the frog body suitable for use as a bioindicator of metal pollution in aquatic and terrestrial environments. Thus, using this species as a biological indicator is an appropriate instrument for future environmental monitoring programs aimed at the conservation of these areas, as well as for the evaluation of the evolution of trace elements within these environments.

\section{CONCLUSIONS}

The samples of sediment and tissue from the $L$. ocellatus amphibian presented high concentrations of certain elements investigated in this study. The species deserves to be carefully studied and preserved to ensure the region's biodiversity. As an abundant species widely distributed throughout the studied region, and due to it being capable of bioaccumulation of metals, the Leptodactylus ocellatus is able to reflect the differences in metal concentrations between different areas analyzed. As Contas River is very important to its surrounding region, a study wasnecessary toidentify abioindicator for environmental monitoring programs. Taking into account the particular characteristics of the amphibian analyzed, it is concluded that the viscera of the L. ocellatus presents a good alternative for use in biomonitoring surveys in the Contas River.

\section{ACKNOWLEDGMENTS}

The authors would like to thank the Coordenação de Aperfeiçoamento de Pessoal de Nível Superior (CAPES), the Conselho Nacional de Desenvolvimento Científico e Tecnológico (CNPq) and the Fundação de Amparo à Pesquisa do Estado da Bahia (FAPESB) for the funding provided. 


\section{RESUMO}

Este trabalho apresenta um estudo sobre a viabilidade de uso de tecidos da espécie Leptodactylus ocellatus (Anura Leptodactylidae) como um bioindicador de poluição por metais. O estudo baseia-se na determinação e correlação das concentrações de manganês, crômio, zinco, níquel, cobre e ferro em sedimentos e tecidos (peles, músculos e vísceras) da rã Leptodactylus ocellatus coletadas na região do médio Rio das Contas, no leste da Bahia. Os mais altos níveis dos metais estudados foram encontrados nas vísceras deste animal. Neste tecido, altas correlações das concentrações destes metais com aquelas encontrados nos sedimentos foram observadas. As concentrações dos elementos encontrados na pele e músculos destes anfíbios não revelaram correlação com os sedimentos onde estes foram coletados. De acordo com os resultados obtidos, as vísceras da espécie L. ocellatus se constituem um bom indicador de contaminação pelos metais estudados.

Palavras-chave: Leptodactylus ocellatus, bioindicadores, sedimentos, metais, Rio de Contas.

\section{REFERENCES}

BARAJ B, Niencheski LF, FiLlmanN G AND HeRmannls L. 2009. Biochemical normalization of trace metals in Arctocephalus australis Brazilian. J Oceanogr 57: 1-6.

Beltrame MO, De Marco SG and Marcovecchio JE. 2011. The burrowing crab Neohelicegranulataas potential bioindicator of heavy metals in estuarine systems of the Atlantic coast of Argentina. Environ Monit Assess 172: 379-389.

Bueno-Guimarães HM, Ferreira CM, Garcia MLB AND SALDIVA PHN. 2001. Tadpole Epithelium Test: potential use of Ranacates beiana histopathologic epithelial changes to evaluate aquatic pollution. Bull Environ Contam Toxicol 67: 202-209.

BulbOvas P ET AL. 2008. Avaliação da sensibilidade de plantas jovens de quiabo (Abelmoschus esculentus (L.) Moench, Malvaceae) ao ozônio. Hoehnea 35: 359-366.

DEPLEDGE MH AND FossI MC. 1994. The role of biomarkers in environmental assessment. Invertebrates. Ecotoxicol 3: $161-172$.

Domingos M. 1998. Biomonitoramento da fitotoxicidade da poluição aérea e da contaminação do solo na região do complexo industrial de Cubatão. São Paulo. utilizando Tibouchina pulchra Cogn. Como espécie indicadora. Tese de doutorado. IB-USP. São Paulo.
EPA - EnVIronmental Protection Agency. 2007. Method 3051. Available via: http://www. caslab. com/EPAMethods/PDF/EPA-Method-3051.pdf. Acessed Jul 2010.

GreEnHouse G. 1976. The evaluation of toxic effects of chemicals in fresh water by using rog embryos and larvae. Environ Pollut 11: 303-315.

JARVisAlo J, OlKINUORA M, KiILUNEN M, Kivisto H, Ristola P, TOSSAVAinen A AND Aitio A. 1992. Unirinary and blood manganese in occupationally non exposed populations and manual metal arc welders of mild steel. Int Arch Occup Environ Health 63: 495-501.

JOHNSON RK, WIEDERHOLM T AND ROSENBERG DM. 1993. Freshwater biomonitoring using individual organisms. populations. and species assemblages of benthic macroinvertebrates. In: Rosenberg DM and Resh VH (Eds), Freshwater Biomonitoring and Benthic Macroinvertebrates. New York: Chapman \& Hall, p. 40-158.

LiANG Y, CHEUNG R AND WONG MH. 1999. Reclamation of wastewater for polyculture of freshwater fish: bioaccumulation of trace metals in fish. Water Res 33: 1690-2700.

MARques SM, ANTUNes SC, NunEs B, GONÇALVES F AND PEREIRA R. 2011. Antioxidant response and metal accumulation in tissues of Iberian green frogs (Pelophylaxperezi) inhabiting a deactivated uranium mine. Ecotoxicol 20: 1315-1327.

Nations S, Wages M, Cañas JE, Maul J, Theodorakis C AND CoBB GP. 2011. Acute effects of $\mathrm{Fe}_{2} \mathrm{O}_{3}, \mathrm{TiO}_{2}, \mathrm{ZnO}$ and CuOnanomaterials on Xenopuslaevis. Chemosphere 83: 1053-1061.

OdUM EP AND BARRETT GW. 2008. Fundamentos de Ecologia. Cengage Learning. $5^{\text {a }}$ ed., São Paulo.

PDRH - Plano DiRETOR DE RECURSOS Hídricos. 1993. Bacia do Rio de Contas. Available via: http://www.biblioteca. inga.ba.gov.br, Acessed Jul 2010.

SÁ TRBT AND SÁ MT. 2004. Os processos espaciais presentes no espaço urbano de Jequié - Bahia. Estudos Geográficos. Rev Eletr Geogr 2: 1-13.

SCHUYTEMA GS AND NEBEKER AV. 1999. Effects of ammonium nitrate, sodium nitrate, and urea on red-legged frogs, Pacific treefrogs and African clawed frogs Bull Environ Contam Toxicol 63: 357-364.

SCHUYTEMA GS, NEBEKER AV, GRIFFIS WL AND WILSON KN. 1991. Teratogenesis, toxicity, and bioconcentration in frogs exposed to dieldrin. Arch Environ Contam Toxicol 21: 332-350.

SRH - SECRETARIA DE RECURSOS HÍDRICOS. 2007. RESOLUÇÃO No 20, DE 23 DE AGOSTO DE 2007. Available via: http:// www.semarh.ba.gov.br/Legislacao/RESOLUCAOCONERH/ CONERHn20prorrogaprazoContas.pdf. Acessed Jul 2010.

WHITTAKER P. 1998. Iron and Zinc interactions in humans. Am J Clin Nutr 68: 442S-446S.

WHO - WORLD HEALTH ORGANIZATION. 1998a. Copper. Geneva. WHO - World Health ORganization. 1998b. Manganese. Geneva. 
